\title{
Analisa Undang-Undang 26 Tahun 2007 terhadap Penyediaan Ruang Terbuka Hijau Berdasarkan Prinsip Good Environmental Governance Di Kota Yogyakarta
}

\author{
Berliant Pratiwi ${ }^{*}$, Eko Priyo Purnomo ${ }^{2}$ \\ ${ }^{1}$ Magister Hukum, Universitas Muhammadiyah Yogyakarta \\ ${ }^{2}$ Magister Ilmu Pemerintahan, Universitas Muhammadiyah Yogyakarta \\ *Correspondence email: berliant.p.psc19@mail.umy.ac.id, eko@umy.ac.id
}

\begin{abstract}
Abstrak. Yogyakarta sebagai salah satu kota yang memiliki jumlah pertumbuhan penduduk yang pesat membutuhkan jumlah ketersediaan ruang yang memadai. Berdasarkan Undang -Undang Nomor 23 Tahun 2007 dan Peraturan Kota Yogyakarta Nomor 2 Tahun 2010 terdapat kewajiban bagi pemerintah setempat untuk melakukan penyediaan ruang terbuka bagi kawasan kota, yaitu sebesar 30\% dari luas wilayah kota terkait. Yogyakarta sendiri sampai dengan tahun 2019 hanya memiliki sebesar 19\% untuk ketersediaan lokasi ruang terbuka hijau. Penelitian ini menggunakan metode normatif yuridis yang akan mengkaji mengenai permasalahan hukum dengan suatu konsep dan asas hukum. Dalam penelitian ini penulis mengangkat permasalahan mengenai penerapan prinsip good environmental governance dalam pengelolaan tata ruang kota yang dianalisa menggunakan teori belbase. Tujuan dari penelitian ini adalah untuk menganalisa penerapan prinsip good environmental governance dalam pengelolaan ruang terbuka hjau di kota Yogyakarta dan mengetahui sejauh mana potensi yang dimiliki oleh kota Yogyakarta dalam upaya penyediaan lokasi ruang terbuka hijau Hasil dari penelitian ini adalah bahwa tercapainya ruang terbuka hijau yang dicita citakan didalam peraturan perundang-undangan bisa diterapkan melalui prinsip prinsip good environmental governance. Tetapi harus diperhatikan terlebih dahulu mengenai permasalahan yang harus dihadapi oleh pemerintah daerah sehingga penerapan prinsip good environmental governance dapat secara optimal diterapkan.
\end{abstract}

Kata Kunci: Good Environmental Governance; Ruang Terbuka Hijau; Pemerintah Daerah

\begin{abstract}
Yogyakarta as one of the cities that has a rapidly growing population requires an adequate amount of space. Based on Law No. 23/2007 and Yogyakarta City Regulation No. 10/2010, there is an obligation for the local government to provide open space for urban areas, which is 30\% of the total area of the city concerned. Yogyakarta itself until 2019 only has $19 \%$ of the availability of green open space locations. This research uses the Normative Juridical method which will examine legal issues with a concept and legal principles. In this research, the writer raises the problem regarding the application of the principles of good environmental governance in urban spatial management which is analyzed using the Belbase Theory. The purpose of this study is to analyze the application of the principles of good environmental governance in the management of green open space in the city of Yogyakarta and to find out the potential of the city of Yogyakarta in providing green open space locations. The results of this study are that the achievement of green open spaces that we aspire to. in laws and regulations can be applied through the principles of good environmental governance. However, it must be considered beforehand regarding the problems that must be faced by local governments so that the implementation of the principles of good environmental governance can be optimally applied.
\end{abstract}

Keywords: Good Environmental Governance; Green Open Space; Local Government

\section{PENDAHULUAN}

Dari waktu ke waktu jumlah peningkatan manusia semakin bertambah secara signifikan. Hal tersebut mengharuskan pemerintah untuk memberikan segala macam kebutuhan baik dari sarana atau kebutuhan pokok hajat hidup orang banyak. Implikasi dari peningkatan tumbuhnya manusia secara signifikan membuat ruang terbuka hijau sedikit demi sedikit terkikis oleh pemanfaatan ruang kota. Dalam Tata Nasional, Kota dijadikan sebagai tempat berkembang dan berubahnya kegiatan ekonomi sosial dan budaya. Maka dari itu penyediaan tempat fasilitas umum dan fasilitas sosial serta ruang terbuka publik sangatlah perlu diberikan perhatian khusus. Pandangan Olivier Schutter, kebutuhan tersebut berbanding terbalik dengan ikut meningkatnya keinginan investasi dari sektor privat. Investasi dalam memang dibutuhkan didalam pembangunan, namun permasalahanya jika terlalu banyak investor yang masuk, maka pemerintah semakin sulit untuk meningkatkan jumlah ruang terbuka hijau, inilah dilemma yang dijumpai oleh pemerintah daerah. ${ }^{1}$

Salah satu fungsi dari keberadaan Ruang Terbuka hijau di tengah pesatnya beraneka ragam pemenuhan kebutuhan ruang bagi manusia adalah untuk menjaga kelestraian lingkungan dan mempertahan citra kebangan identitas kota. Pembagian ruang terbuka hijau selanjutnya dalam artikel ini disebut Ruang Terbuka Hijau (RTH)

${ }^{1}$ Olivier Schutter, "The Green Rush: The Global Race for Farmland and the Rights of Land Users," Harvard International Law Journal 52, no. 2 (2011): 503-59. Hlm 525 
berdasarkan Undang-Undang Nomor 26 Tahun 2007 didalamnya membahas mengenai pemberian kewajiban kepada setiap Kota untuk menyediakan dan menyisihkan sebesar $10 \%$ untuk kepentingan privat dan $20 \%$ untuk kepentingan publik sehingga total penyediaan Ruang Terbuka Hijau (RTH) yang diwajibkan adalah sebesar 30\%. Penyediaan Ruang Terbuka Hijau (RTH) dalam rangka menjaga kualitas lingkungan menjadi Tanggung Jawab seluruh pejabat terkait,swasta dan masyarakat.

Pada tahun 1992 terjadi suatu kesepakatan yang berlangsung di Brasil dalam bentuk suatu Konferensi Tingkat Tinggi (KTT) yang membahas tentang Urgensi Penyediaan Ruang Terbuka Hijau (RTH) di perkotaan, kemudian ditegaskan kembali dalam Konferensi Tingkat Tinggi (KTT) pada tahun 2002 di Afrika Selatan dengan pembahsan yang sama yaitu mengenai penyediaan idealnya suatu Ruang Tata Hijau (RTH) dalam suatu kota. Di luar dari hukum pokok yang terdiri dari Konferensi Internasional dan Undang-Undang Nasional terkait, ada juga Peraturan Perundangan-Undangan yang bisa digunakan oleh Pemerintah Daerah dalam rangka melakukan dan mewujudkan Ruang Tata Hijau (RTH) agar dapat bermanfaat bagi lingkungan, antara lain, Undang Undang Nomor 27 tentang Penataan Ruang ,Keputusan Presiden Nomor 32 Tahun 1990 yang membahas tentang Pengelolaan Suatu Kawasan Hutan Lindung.

Menurut D. M. Ong pada artikel yang berjudul The Impact of Environmental Law on Corporate Governance: International and Comparative Perspectives, penentuan dan pengelolaan tata ruang suatu kota yang berwawasan lingkungan, pemerintah wajib memberikan upaya nyata berkaitan dengan pemberian penganwasan terhadap pelaksanaan suatu rencana Tata Kelola Ruang Terbuka Hijau. Bisa dibilang ini menimbulkan potensi adanya integrasi masalah lingkungan di dalam perusahaan dan masyarakat(sektor privat) oleh pemerintah, maka proses pengambilan keputusan menjadi sangat krusial dalam penentuan dan pengelolaan tata ruang kota. ${ }^{2}$ Indonesia sebagai Negara yang sedang melakukan pembangunan secara signifkan pada tiap kota besarnya yang beriringan dengan teknologi yang semakin maju dan berkemabang, harus mampu memberikan suatu pengawasan yang mengacu dan mementingkan tujuan kota, perencanaan tata kelola ruang terbuka hijau (RTH) dan pelaksanaanya.

Yogyakarta merupkan salah satu bagian dari sekian banyak daerah di Indonesia yang beroreintasi untuk melaksankan suatu proses pembagunan.Hal tersebut menyebabkan tidak dapat di tepisnya suatu kenyataan mengani pengalokasian dan pemanfatan lahan secara besar besaran guna mewujudkan tercapiny suatu proses pembagunan. Pengalih Fungsian Ruang terbuka hijau dapat dilaksanakan dalam suatu proses pebagunan dikarenakan semakin pesatnya permintaan kebutahan masyarakat setempat yang berbanding teralik dengan ketersediaan ukuran lahan.

Berdasarkan data dari Dinas Lingkungan Hidup Daerah Istimewa Yogyakarta melalui website resmi dan berita online, pada tahun 2014 terdapat 35 lokasi Ruang Terbuka Hijau (RTH) dan pada tahun 2019 terdapat 47 lokasi Ruang Terbuka Hijau (RTH) diseluah luas wilayah Yogyakarta. ${ }^{3}$ Jika diprosentasikan ditahun 2019, hanya terdapat $19 \%$ wilayah Ruang Terbuka Hijau (RTH) di kota Yogyakarta. Sedangkan seperti yang sudah dijabarkan diatas bahwa mandat dari Undang-Undang nasional dan Konferensi Internasional memberikan ketentuan minimal bagi suatu kota berwawasan lingkungan harus menyediakan 30\% untuk Ruang Terbuka Hijau (RTH). Dari penjelasan latar belakang diatas, maka menarik apabila dalam penulisan artikel ini menganalisa mengenai pengelolaaan Ruang Terbuka Hijau (RTH) di Kota Yogyakarata jika dikatan dengan prinsip prinsip dari Good Environmental Governance.

\section{METODE}

\section{Pendekatan Penelitian}

Dalam penelitian ini penulis menggunakan metode penelitian yuridis normatif pendekatan yang dilakukan berdasarkan bahan hukum utama dengan cara menelaah teori-teori, konsep konsep, asas-asas hukum serta peraturan perundang-undangan yang berhubungan dengan penelitian ini. Pendekatan ini dikenal pula dengan pendekatan kepustakaan, yakni dengan mempelajari buku-buku, peraturan perundang-undangan dan dokumen lain yang berhubungan dengan penelitian ini. Mencoba untuk menganalisa sejauh mana prinsip-prinsip Good Environmental Governance diterapkan dalam pengelolaan Ruang Terbuka Hijau (RTH) di Kota Yogyakarta.

Adapun pendekatan penelitian yang digunakan penulis dalam penelitian ini adalah deskriptif analisis, adapun pengertian dari metode deskriptif analitis adalah suatu metode yang berfungsi untuk mendeskripsikan atau memberi gambaran terhadap objek yang diteliti melalui data atau sampel yang telah terkumpul sebagaimana adanya tanpa melakukan analisis dan membuat kesimpulan yang berlaku untuk umum. ${ }^{4}$ Dengan kata lain penelitian deskriptif analitis mengambil masalah atau memusatkan perhatian kepada masalah-masalah sebagaimana adanya saat penelitian dilaksanakan, hasil penelitian yang kemudian diolah dan dianalisis untuk diambil kesimpulannya yang terkait.

${ }^{2}$ D. M. Ong, "The Impact of Environmental Law on Corporate Governance: International and Comparative Perspectives," European Journal of International Law 12, no. 4 (2001): 685-726, https://doi.org/10.1093/ejil/12.4.685. Hlm 689

${ }^{3}$ Pribadi Wicaksono, "Kiat Pemkot Yogyakarta Membuat Wilayahnya Makin Asri'," 2020, https://travel.tempo.co/read/1310249/kiat-pemkot-yogyakarta-membuat-wilayahnya-makin-asri. Akses 19 Oktober 2020

${ }^{4}$ Sugiyono, Metode Penelitian Kuantitatif, Kualitatif Dan R\&D (Bandung: Alfabeta, 2009). Hlm 67 


\section{Sumber Data Dan Alat Pengumpulan Data}

Data Sekunder merupakan sumber data suatu penelitian yang di peroleh peneliti secara tidak langsung melalui media perantara (di peroleh atau dicatat oleh pihak lain). Data sekunder itu berupa bukti,catatan atau laporan historis yang telah tersusun dalam arsip atau data dokumenter. Penulis mendapatkan data sekunder ini dengan cara melakukan permohonan ijin yang bertujuan untuk meminjam bukti-bukti transaksi pada usaha woodshouse dan buku yang di gunakan untuk pencatatan transaksi setiap harinya.

\section{Analisis Data}

Analisis data dalam penelitian ini menggunakan analisis kualitatif, artinya menguraikan konsep hukum secara rinci ke dalam sutu isu permasalahan melalui pemikiran (deskriptif). Analisis kualitatif yang dilakukan bertitik tolak dari analisis normatif. Berdasarkan hasil analisis ditarik kesimpulan secara dedukatif, yaitu cara berpikir yang didasarkan pada fakta-fakta yang bersifat umum untuk kemudian ditarik suatu kesimpulan bersifat khusus

\section{HASIL DAN PEMBAHASAN}

\section{Keterakitan Antara Konsep Good Environmental Goverence Dengan Pengelolaan Ruang Terbuka Hijau}

Menurut Eko Budiharjo \& Djoko Sujarto dalam bukunya yang berjudul Kota Berkelanjutan ruang terbuka merupakan ruang yang direncanakan karena kebutuhan akan tempat-tempat pertemuan dan aktivitas bersama di udara terbuka. Dengan adanya pertemuan bersama dan relasi antara orang banyak, kemungkinan akan timbul berbagai macam kegiatan di ruang umum terbuka tersebut. Keberadaan dari ruang terbuka adalah salah satu jenis bagian dari ruang umum. Berdasarkan Undang-Undang Nomor 26 Tahun 2007 yang membahas mengenai Penataan Ruang, yang dimaksud dengan Ruang Terbuka Hijau adalah suatu area yang memanjang atau jalur dan atau mengelompok. Menjadi salah satu tempat tumbuh dan berkembangnya jenis jenis tanaman yang dapat tumbuh secara alamiah atau dengan metode penanaman. Maka dari itu keberadaan dari ruang terbuka hijau (RTH) menjadi salah satu unsur terpenting yang harus dimiliki oleh suatu wialayah Perkotaan, hal tersebut dikarenakan dengan adanya ruang terbuka hijau (RTH) Secara arsitektural dapat meningkatkan nilai keindahan dan kenyamanan kota melalui keberadaan taman-taman kota, kebun-kebun bunga, dan jalur-jalur hijau di jalan-jalan kota.

Peran pemerintah dalam penyediaan ruang terbuka hijau yang dapat dimanfaatkan oleh khalayak ramai erat hubunganya dengan penentuan kebijakan public. Menurut James Anderson dalam bukunya Public Policy Making, memberikan definisi kebijakan publik adalah serangkaian kegiatan yang mempunyai maksud/tujuan tertentu yang diikuti dan dilaksanakan oleh seorang aktor atau sekelompok aktor yang berhubungan dengan suatu permasalahan atau suatu hal yang diperhatikan. ${ }^{5}$ Konsep dari kebijakan ini menitikberatkan pada apa yang sesungguhnya dikerjakan daripada apa yang diusulkan atau dimaksud. Kebijakan publik adalah keputusan-keputusan yang mengikat bagi orang banyak pada tataran strategis atau bersifat garis besar yang dibuat oleh pemegang otoritas publik. Konsep kebijakan publik yang dikemukakan oleh Anderson, memiliki beberapa implikasi yakni, ${ }^{6}$ (1) Pusat perhatian kita dalam membicarakan kebijakan publik tidak berorientasi pada perilaku secara serampangan melainkan lebih tertuju pada maksud atau tujuan. Kebijakan publik secara luas dalam sistem politik modern, bukan sesuatu yang terjadi begitu saja melainkan telah direncanakan oleh aktor-aktor yang terlibat di dalam sistem politik. (2) Kebijakan merupakan suatu arah atau pola tindakan yang dilakukan oleh pejabat-pejabat pemerintah dan bukan merupakan keputusan-keputusan yang tersendiri. Cakupan yang ada di dalam suatu kebijakan tidak hanya membahas terkait keputusan untuk menetapkan peraturan tertentu, tetapi juga membahas tata cara pelaksanaan dari keputusan-keputusan tersebut.

Purnomo Hadi, dalam tesis yang ditulisnya dengan judul Peran Ruang Terbuka Hijau Dalam Pengendalian Kualitas Udara di DKI Jakarta, Ruang Terbuka Hijau (RTH) merupakan:

1. Suatu lapang yang ditumbuhi berbagai tetumbuhan, pada berbagai strata, mulai dari penutup tanah, semak, perdu dan pohon (tanaman tinggi berkayu);

2. Sebentang lahan terbuka tanpa bangunan yang mempunyai ukuran, bentuk dan batas geografis tertentu dengan status penguasaan apapun, yang didalamnya terdapat tetumbuhan hijau berkayu dan tahunan (perennial woody plants), dengan pepohonan sebagai tumbuhan penciri utama dan tumbuhan lainnya (perdu, semak, rerumputan, dan tumbuhan penutup tanah lainnya), sebagai tumbuhan pelengkap, serta benda-benda lain yang juga sebagai pelengkap dan penunjang fungsi RTH yang bersangkutan. ${ }^{7}$

Manfaat Ruang Terbuka Hijau menurut Peraturan Menteri dalam Negeri No. 1 tahun 2007 Tentang Penataan Ruang Terbuka Hijau Kawasan Perkotaan, adalah sebagai berikut:

\footnotetext{
${ }^{5}$ Purnomo Hadi, "Peran Ruang Terbuka Hijau Dalam Pengendalian Kualitas Udara Di DKI Jakarta" (Institut Pertanian Bogor, 1995), http://repository.ipb.ac.id/handle/123456789/955. Akses 20 Oktober 2020

${ }^{6}$ Kodoatie dan Syarief, Tata Ruang Air (Yogyakarta: Andi Offset, 2010).

${ }^{7}$ Purnomo Hadi, "Peran Ruang Terbuka Hijau Dalam Pengendalian Kualitas Udara Di DKI Jakarta.” Hlm 65
} 
1. Sarana untuk mencerminkan identitas daerah.

2. Sarana penelitian, pendidikan, dan penyuluhan.

3. Sarana rekreasi aktif dan pasif serta interaksi sosial.

4. Meningkatkan nilai ekonomi lahan perkotaan.

5. Menumbuhkan rasa bangga dan meningkatkan prestise daerah.

6. Sarana aktivitas sosial bagi anak-anak, remaja, dewasa, dan manula.

7. Sarana ruang evakuasi untuk keadaan darurat.

8. Memperbaiki iklim mikro; dan

9. Meningkatkan cadangan oksigen di perkotaan

Manfaat yang dapat diperoleh dari ruang terbuka hijau kota antara lain memberikan kesegaran, kenyamanan dan keindahan lingkungan; memberikan lingkungan yang bersih dan sehat bagi penduduk kota dan memberikan hasil produksi berupa kayu, daun, bunga dan buah. ${ }^{8}$

Artinya bahwa keberadaan dari suatu Ruang Terbuka Hijau dapat dijadikan sebagai salah satu tempat untuk berkumpul, melakukan interkasi sosial sekaligus tempat untuk relaksasi bagi masyarakat serta dapat meningkatkan kualitas lingkungan karena dapat mengurangi polusi yang dapat mengganggu kesehatan. Oleh karena itu Ruang Terbuka Hijau (RTH) di Yogyakarta, menjadi salah satu komponen dari penataan ruang kota yang memiliki manfaat besar dan arti penting bagi masyarakat. Maka dari itu pemerintah harus senantiasa memperhatikan pelaksanaan dari penerapan Ruang Terbuka Hijau (RTH) agar terus dapat meningkatkan kulalitas dan kuantias RTH didaerahnya. Pernyataan diatas menjelaskan mengenai suatu ruang terbuka hijau yang bersifat publik tidak hanya dapat dimanfaatkan untuk kehidupan manusia saja, namun juga bermanfaat untuk keberlagsungan kehidupan satwa. Dapat membantu untuk terhindar dari polusi udara karena berfungsi membersihkan udara dan air, merupakan beberapa contoh dari pentingnya keberadaan suatu ruang terbuka hijau.

Ruang terbuka hijau terdiri dari ruang terbuka hijau publik dan ruang terbuka hijau privat. ${ }^{9}$ Ruang terbuka hijau public adalah RTH yang dikelola oleh pemerintah sedangkan Ruang Terbuka Hijau privat yang dikuasai oleh swasta ataupun masyarakat. Hal tersebut menjadi salah satu dasar bahwa keseluruhan Lahan di perkotaan dimiliki oleh pemerintah, masyarakat, dan swasta. Bentuk Ruang Terbuka Hijau menurut Peraturan Departemen Pekerjaan Umum Tahun 2008 tentang Pedoman Penyediaan dan Pemanfaatan Ruang Terbuka Hijau di Kawasan Perkotaan terbagi kedalam beberapa bentuk

\begin{tabular}{lll}
\hline \multicolumn{1}{c}{$\begin{array}{c}\text { Berdasarkan bobot } \\
\text { kealamiannya }\end{array}$} & \multicolumn{1}{c}{$\begin{array}{c}\text { Berdasarkan sifat dan } \\
\text { karakter ekologisnya }\end{array}$} & \multicolumn{1}{c}{$\begin{array}{c}\text { Berdasarkan penggunaan lahan atau kawasan } \\
\text { fungsionalnya }\end{array}$} \\
\hline $\begin{array}{l}\text { Bentuk RTH alami (habitat } \\
\text { liar/alami, kawasan lindung) }\end{array}$ & Bentuk RTH kawasan (areal) & $\begin{array}{l}\text { Ruang Terbuka Hijau kawasan perdagangan } \\
\text { Ruang Terbuka Hijau kawasan perindustrian } \\
\text { Ruang Terbuka Hijau kawasan permukiman }\end{array}$ \\
$\begin{array}{l}\text { Bentuk RTH non alami atau bentuk RTH jalur (koridor) } \\
\text { RTH binaan (pertanian kota, } \\
\text { pertamanan kota, lapangan olah } \\
\text { raga, pemakaman }\end{array}$ & $\begin{array}{l}\text { Ruang Terbuka Hijau kawasan pertanian } \\
\text { Ruang Terbuka Hijau kawasan-kawasan khusus, seperti } \\
\text { pemakaman, olah raga, alamiah. }\end{array}$ \\
\hline
\end{tabular}

Merujuk pada pandangan Sadyohutomo \& Mulyono, bentuk-bentuk Ruang Terbuka Hijau yaitu;

1. Hutan Kota

2. Kuburan Jalur sempadan jalan;

3. Lapangan olahraga;

4. Jalur khusus sepeda dan pejalan kaki;

5. Perairan (waterfront); sungai, kolam, danau, dan tepian laut;

6. Ruang terbuka privat, yaitu halaman, taman (garden) termasuk roof garden, teras rumah, dan sempadan bangunan;

7. Atrium pada komplek bangunan besar (plaza,mal);

8. Taman yang bersifat publik (parks), yaitu taman kota, alun-alun, taman bermain, dan taman pada lingkungan permukiman. ${ }^{10}$

Pola pemanfaatan ruang yang dilakukan secara structural akan memberikan bentuk tata ruang kota yang direncanakan maupun tidak. Sumber daya alam, Pengelolaan Lingkungan, Penataan Ruang, merupakan factor yang

\footnotetext{
${ }^{8}$ Fitrina Faizah, "Model Sistem Dinamis Ruang Terbuka Hijau Kota Medan Berdasarkan Faktor - Faktor Lingkungan (Studi Kasus Di Kecamatan Medan Polonia Dan Medan Area)" (Universitas Sumatera Utara, 2012). Hlm 72

${ }^{9}$ Kodoatie dan Syarief, Tata Ruang Air. Hlm 45

${ }^{10}$ Sadyohutomo and Mulyono, Manajemen Kota Dan Wilayah Realita Dan Tantangan (Jakarta: Bumi Aksara, 2009). Hlm 
dapat mempegaruhi kondisi keadaan masyarakat seacara ekonomi dan sosial. ${ }^{11}$ Sumber daya mansuia dipegaruhi oleh keberadaan tempat dan budaya dari masyarakat yang berhubungan lagsung dengan penataan ruang kota. Hal Hal lain yang perlu diperhatiakan dalam proses perencanaan suatu kota diantaranya ialah:

1. Proses Penyusunan perencanaan;

2. Proses Pemanfaatan;

3. Proses Pengendali.

Mewujudkan pembagunana kota yang berwawasan lingkungan sebaiknya mempriotaskan segala manfaat dari unsur dan elemen tata ruang kota, agar dapat membuat kota Yogyakarta menjadi kota yang berwawasan lingkungan secara efektif. Pelaksanaaan konsep Good Environmental Governance dilakukan dengan cara memperhatikan pengelolaan lingkungan yang berdasar pada keberlanjutan sumber daya alam demi dapat menyelengarakan tatanan negara yang baik. ${ }^{12}$

Pernyataan diatas menejelaskan mengenai Perlindungan atas kuliatias hidup mansuia dan kuliatias lingkungan tergantung dari baik burunya kegitaan pemerintah secara berkelaanjutan atau tidak. Budiati dalam hal ini mengenai salah satu argumenya yaitu pengelolaan kekayaan negara dalam hal ini sumber daya alam merupakan salah satu cara bagi pihak pemerintah untuk berinteraksi dengan rakyat dalam rangka sebagai upaya memenuhi kewajibanya sesuai dengan Undang-Undang Dasar 1945 dan mewujudkan pelaksanaan dari konsep enviomental governance. ${ }^{13}$

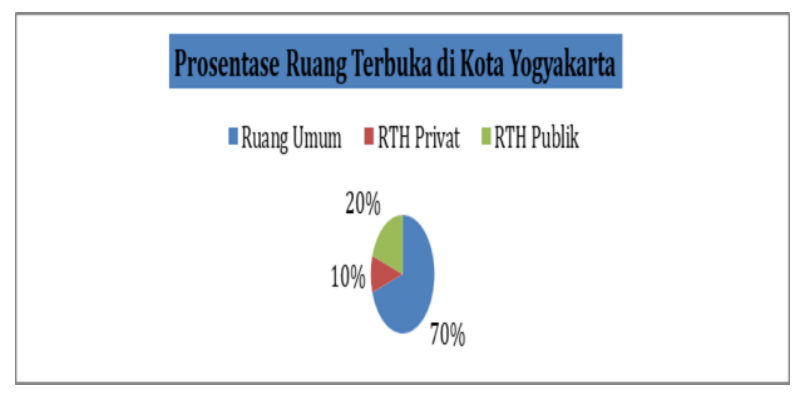

\section{Penerapan Undang-Undang 26 Tahun 2007 Tentang Penataan Ruang Oleh Pemda Yogyakarta Dalam Penyediaan Ruang Terbuka Hijau}

Undang - Undang Nomor 26 Tahun 2007 menjelaskan tentang suatu kota wajib menyediakan ruang terbuka hijau sebesar 30\% dengan pembagian 20\% untuk ruang terbuka hijau publik dan 10\% untuk ruang terbuka hijau privat. Penyediaan kawasan ruang terbuka hijau yang ada di kota Yogyakarta bila dilihat dari dari peraturan daerah kota Yogyakarta nomor 2 tahun 2010 yang mewajibkan ketersedian kawasan ruang terbuka hijau sebesar 30\%, maka hal ini juga sesuai dengan konverensi tingkat tinggi yang berlgsung di brazil dan afrika selatan.

Kewajiban ini hingga tahun 2019, terlebih penyediaan kawasan ruang terbuka hijau public sangat sulit dilksanakan oleh pemerintah daerah kota Yogyakarta, kesulitan untuk memenuhi luasan ruang terbuka hijau sebesar $30 \%$ sesuai Undang-Undang Penataan Ruang karena keterbatasan lahan selain laju pembangunan kota yang dinamis. Setiap kota atau kabupaten di Indonesia harus memiliki ruang terbuka hijau minimal $30 \%$ dari luas wilayah. Namun, target tersebut sepertinya sulit tercapai meskipun tidak ada batasan waktu untuk pemenuhannya.

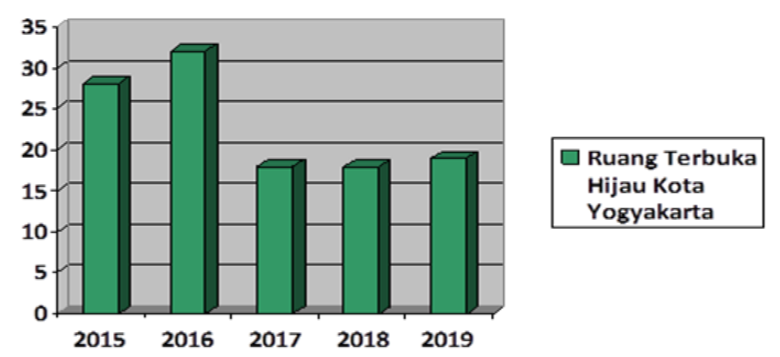

Sumber: Dinas Lingkungan Hidup Kota Yogyakarta

Menjadi isu utama dalam tiga tahun terakhir di kota Yogyakarta adalah meningatnya sisi perekonomian masyarakat, hal ini tentu juga berpegaruh dalam penyediaan kawasan ruang terbuka hijau. Ketidakseimbangan yang

\footnotetext{
${ }^{11}$ Mirsa \& Rinaldi, Elemen Tata Ruang Kota (Yogypakarta: Graha Ilmu, 2011). Hlm 87

12 N.H.T Siahaan, Hukum Lingkungan Dan Ekologi Pembangunan (Jakarta: Erlangga, 2004). Hlm 56

${ }^{13}$ Budiati, Good Governance Dalam Pengelolaan Lingkungan Hidup (Bogor: Ghalia Indonesia, 2012). Hlm 23
} 
terjadi di Kota Yogyakarta adalah dilihat dari sisi perekonomiannya, mengalami peningkatan dari tahun ke tahun, namun berbanding terbalik bila dilihat dari sisi konsep pembangunan berkelanjutan dan pembangunan kualitas hidup manusia yang semakin mengalami penurunan. Meski begitu, tidak mudah bagi pemerintah kota untuk melaksanakan konsep pembangunan berkelanjutan yang ditopang oleh infrastruktur memadai. Sementara itu, tuntutan lain yang dihadapi oleh pemerintah adalah dalam hal perubahan pola hidup masyarakat dan dampak sosial yang ditimbulkan dari kebijakan pembangunan yang berorientasi ekonomi.

Edi Suharto berpendapat bahwa diperlukan keseimbagan dalam pesatnya laju perekonomian kota dan ketersediaan kawasan ruang terbuka hijau, bisa didapatkan dengan pendekatan yang ideal dari pemerintah untuk masyarakat umum, dengan cara memperhatikan kebijakan sosial dan perlindungan sosial ${ }^{14}$, dengan menitikberatkan segala kebijakan yang dibuat untuk meningkatkan kesejahteraan rakyat terutama pemberiaan jaminan sosial seperti kesehatan dalam bentuk memberikan upaya semaksimal mungkin untuk penyediaan oksigen yang bersih dan sehat melalui kawasan terbuka hijau. Kembali merujuk pada pandangan Olivier Schutter, kepemilikan atau penyewaan tanah dalam skala besar menimbulkan sejumlah pertanyaan mendesak, termasuk apakah investasi semacam itu akan berkontribusi pada ketahanan pangan lokal atau malah membuat kelompok berisiko menjadi kurang aman, apakah jenis pertanian yang menjadi tujuan investasi ini adalah ramah lingkungan berkelanjutan, dan bagaimana pemerintah harus mengatur fenomena ini. ${ }^{15}$

Soal ruang terbuka hijau (RTH), di wilayah Kota Yogyakarta beberapa tahun terakhir dirasa sulit untuk mendapatkan lahan kosong guna dialokasikan menjadi kawasan RTH. Hal tersebut dapat dibuktikan dengan meningkatnya jumlah penduduk yang tinggal di bantaran sungai. Terkait hal ini sudah seharusnya dilakukan tindakan relokasi karena sungai masuk ke dalam kategori ruang terbuka hijau. Namun, untuk melakukan relokasi tanpa menyiapkan lahan pengganti juga bukan perkara mudah. Dibutuhkan persiapan dan fasilitas yang memadai karena jangan sampai kegiatan relokasi ini mencabut hajat hidup mereka dari lingkungan asalnya. Mungkin ide ini mudah diucapkan tapi susah diterapkan, untuk membenahi tata ruang Kota Yogyakarta yang menghadapi berbagai kompleksitas permasalahan pembangunan ini diperlukan kesadaran dari pemimpin dan masyarakat untuk secara bersama-sama mengatasi tata kota yang lebih baik dan nyaman untuk ditinggali.

Sebenarnya jika perturan mengenai kawasan terbuka hijau didasarkan pada peraturan menteri dalam negeri nomor 4 tahun 1996 maka ketersediaan kawasan ruang terbuka hijau dikota Yogyakarta telah memenuhi kewajiban terhadap undang-undang nomor 26 tahun 2007 dan KTT Internasional yaitu sebesar 32\% dari luas wilayah administrasi kota Yogyakarta. Hal ini karena penentuan kriteria ruang terbuka hijau telah dirubah menjadi:

\begin{tabular}{ll}
\hline Berdasarkan Permendagri No. 1 Tahun 2007 & Berdasarkan Permen PU No.5/PRT/M/2008 \\
\hline Taman Kota & RTH Pekarangan \\
Taman Wisata Alamaman & RTH Halaman \\
$\begin{array}{l}\text { Rekreasi Taman } \\
\text { Lingkungan Perumahan dan Permukima } \\
\text { Taman Lingkungan }\end{array}$ & Perkantoran, Pertokoan, dan Tempat Usaha \\
$\begin{array}{l}\text { Perkantoran dan Gedung Komersialaman } \\
\text { Hutan Raya }\end{array}$ & RTH dalam Bentuk Taman Atap Bangunan (Roof \\
Hutan Kota & Garden)TH Taman Rukun Tetangga \\
$\begin{array}{l}\text { Hutan Lindung } \\
\text { Bentang Alam seperti Gunung, Bukit, Lereng dan Lembah }\end{array}$ & RTH Taman Rukun Warga \\
$\begin{array}{l}\text { Cagar Alam } \\
\text { Kebun Raya }\end{array}$ & RTH Kelurahan \\
Kebun Bintang & \\
$\begin{array}{l}\text { Pemakaman Umum } \\
\text { Lapangan Olah Raga }\end{array}$ & RTH Kecamatan \\
Lapangan Upacara & \\
$\begin{array}{l}\text { Parkir Terbuka } \\
\text { Lahan Pertanian }\end{array}$ & RTH Taman Kota \\
$\begin{array}{l}\text { PerkotaanJalur Dibawah Tegangan Tinggi } \\
\text { Sempadan Sungai } \\
\text { Pantai, Bangunan, Situ dan Rawalur }\end{array}$ & Hutan Kota \\
$\begin{array}{l}\text { Pengaman Jalan, Median Jalan, Rel Kereta Apu, Pipa Gas dan Pedestrian } \\
\text { Kawasan dan Jalur HijauDaerah Penyangga (Buffer Zone) Lapangan } \\
\text { UdaraTaman Atap }\end{array}$ & Sabuk Hijau \\
\hline
\end{tabular}

${ }^{14}$ Edi Suharto, Membagun Masyarakat Memberdayakan Masyarakat : Kajian Strategis Pembagunan Kesejahteraan Sosial Dan Pekerjaan Sosial (Bandung: Refika Aditama, 2006). Hlm 51

${ }^{15}$ Schutter, "The Green Rush: The Global Race for Farmland and the Rights of Land Users." Hlm 542 
Banyaknya kriteria yang terdapat di dalam peraturan di atas tentang ruang terbuka hijau bukan berarti memperbesar kemungkiinan mudahnya penentuan ruang terbuka hijau di kota yogyakarta. Hal ini dikarenakan didalam pertaturan daerah kota Yogyakarta nomor 2 tahun 2010 bahwa penyediaan kawasan ruang terbuka hijau harus didasarkan pada asas kemanfaatan dan asas kelestarian. Hal ini sesuai dengan yang di nyatakan oleh JE Hosio, dalam bukunya yang berjudul, Kebijakan Publik dan Desentralisasi Esai dari Sorong, Bahwa hal ini terdapat kesinambungan dengan teori kebijakan pemerintah, segala keputusan pemerintah harus didasarkan pada kepentingan rakyat yang terdiri dari perpaduan antara pendapat, keinginan, dan tuntuan rakyat yang disampaikan kepada pemerintah. ${ }^{16}$

Kebijakan terkait penyediaan ruang terbuka hijau harus dilaksanakan secara tepat sasaran, maksudnya, ruang terbuka didalam suatu kota harus memenuhi jumlah kualitas dan kuantitas sehingga masyarakat akan mampu merasakan dampak yang signifikan terhadap adanya kawasan tersebut. Menurut Rian Nugroho, Jika masyarakat telah mampu merasakan manfaat dari keberadaan kawasan ruang terbuka hijau disekitarnya maka diharapkan pembagunan nasional akan mengalami transisi yang dicita-citakan dengan adanya kebijakan tersebut. ${ }^{17}$

Penerapan atas penyediaan kawasan terbuka hijau oleh pemerintah kota Yogyakarta jika didasarkan pada undang-undang nomor 26 tahun 2007 dirasa telah maksimal tetapi masih ada tantangan tantangan yang belum bisa diselesaikan, sehingga menyebabkan penyediaan kawasan ruang terbuka hijau masih sebesar 19\% pada tahun 2019, belum memenuhi kewajiban sebesar $30 \%$. Penulis berpendapat bahwa penyediaan ruang terbuka hijau tidak bisa dilakukan begitu saja dengan langsung menargetkan pada kuantitasnya saja, karena hanya akan membebani anggaran daerah kota yogygakarta. Hal yang bisa dilakukan oleh pemerintah kota Yogyakarta adalah dengan cara memprioritaskan pada ruang terbuka hijau yang telah ada untuk ditingkatkan kualitas dan menjaga kelestarian ruang tersebut. Jika memang dibutuhkan penambahan kawasan ruang terbuka hijau, pemerintah kota Yogyakarta bisa memberikan kewenagan kepada tiap-tiap kecamatan untuk menyediakan setidaknya satu ruang terbuka hijau diwilayahnya. Hal yang demikian akan memberikan tanggung jawab kepada pionir terkecil dari pemerintah untuk menjaga dan mengawasi ketersediaan ruang terbuka hijau, sekaligus bisa memberikan penyuluhan terhadap masyarakat sekitar akan pentingnya ruang terbuka hijau untuk kehidupan disekitar. Tetapi dalam pandangan Soetandyo Wigjoesoebroto, tetap saja akan ada tantangan tersendiri bagi struktur terkecil ini, yaitu sering terjadinya control sosial yang tidak bisa dijalankan secara penuh oleh agen agen sosial, bukan karena kondisi objektiv tetapi karena sikap intoleran sehingga terjadi pelanggaran-pelanggaran norma dalam masyarakat. ${ }^{18}$

Menurut Wahidatul Rizqi Firianti, dalam artikelnya dengan judul Pengembangan Ruang Terbuka Hijau Kawasan Sungai Winongo Di Kricak Kota Yogyakarta, bahwa pendekatan yang dapat digunakan oleh pemerintah kota Yogyakarta dalam mengajak masyarakat setempat untuk ikut berpartisipasi dalam pengembangan ruang terbuka hijau adalah pendekatan Gandeng-Gendong. Artinya, Kegiatan dalam pegembagan RTH ini harus memiliki win-win solution bagi pemerintah maupun masyarakat. Prioritas yang difokuskan dalam pendekatan ini adalah mengupayakan kebersamaan masyarakat dalam melakukan segala macam bentuk kegiatan yang berdampak baik bagi lingkugan hidup disekitarnya sekaligus sebagai langkah untuk membantu pihak yang membutuhkan dibidang ekonomi. Bentuk dari pendekatan ini dicerminkan dalam pengembagan kawasan tempat pembuagan akhir yang dilakukan bersama sama oleh pemerintah dan masyarakat. Terpenuhinya cita-cita penyediaan kawasan RTH adalah dampak positif dari adanya pendekatan ini, sedangkan bagi masyarakat di sekitar lingkungan agar bisa menjadi tempat atau ruang warga dalam berkegiatan mengingat keterbatasan lahan yang ada di perkotaan.

\section{Penerapan Prinsip Good Environmental Goverence Terhadap Penyediaan Ruang Terbuka Hijau Di Kota Yogyakarta}

Penulis dalam melakukan analisa pada bab ini meminjam konsep pemikiran dari Narayan Belbase, yang menulis mengenai The Implementation Of International Environmental Law in Nepal, yang didalam tulisanya tersebut mencoba membedah regulasi yang diterapkan negara Nepal dalam pengelolaan lingkungan, Dalam pemikirianya tersebut penulis mencoba menerapkan konsep Good Environmental Governance yang dijabarkan oleh Narayan Belbase dalam hal penyediaan kawasan ruang terbuka hijau oleh Pemkot Yogyakarta, ada 6 faktor yanag mampu menjadi acuan dalam konsep ini, meliputi, pertama, pembatas kewenagan oleh hukum, dua konsep yang terdapat dalam aturan hukum adalah yang pertama dengan adanya keberadaan dari aturan hukum membuat pemerintah tdak melakukan hal hal yang terkesan sewenang wenangan dalam pelaksaan aturan hukum, Yang kedua pelaksanaan aturan hukum harus berdasarkan pada hukum legal atau hukum yang seusai dengan peraturan perundang undangan yang berlaku dan hal lain yang tidak dapat dilupakan adalah suatu aturan hukum tersebut haruslah berdasarkan keningginan atau kebutuhan masyarakat bukan suatu aturan hukum yang berdasarkan pada kemauaan pihak pihak tertentu.

\footnotetext{
${ }^{16}$ J.E. Hosio, Kebijakan Publik Dan Desentralisasi Esai Dari Sorong (Yogyakarta: LaksBang, 2007). Hlm 45

${ }^{17}$ Rian Nugroho, Metode Penelitian Kebijakan (Yogyakarta: Pustaka Pelajar, 2013). Hlm 3

${ }^{18}$ Soetandyo Wigjoesoebroto, Hukum Dalam Masyarakat (Jakarta: Rajawali, 1986). Hlm 18
} 
Dapat ditarik kesimpulan dari dua konsep terakit aturan hukum datas bahwa dengan adanya keberadaan aturan hukum maka akan membuat kepentingan masyarakat terlindung dengan baik dari tindakan kesewenang weangan yang dapat di lakukan dengan mudah oleh para pihak pihak yang tidak bertanggung jawa. Di Kota Yogyakarta sendiri aturan hukum terkait pengelolaan Ruang Terbuka Hijau diatur dalam Peraturan Daerah Nomor 2 Tahun 2010 tentang Rencana Tata Ruang Wilayah Yogyakarta. Semua aturan aturan yang terakit dengan khusunya dengan pelaksanaan Ruang Tebuka Hijau harus ditaati oleh semua pihak khsusunya masyarakat Yogyakarta. Kebijaksanaan pemerintah diperlukan dalam hal implementasi pelaksanaan tata ruang kota, khusunya contohnya dalam sengketa antara pemerintah dengan masyarakat umum seperti sengekata lahan. insentif dan disinsentif adalah cara yang dimiliki pemerintah untuk elaksanakan penerapan Ruang Terbuka Hijau di Yogyakarata .

Sebagai contoh nyata dari kedua cara diatas adalah apabila ada pihak yang akan menggunakan lahan yang ia milki untuk dgunakan sebagai Ruang Terbuka Hijau maka daripihak pemerintah akan memberikan keringan dalam pembayaran pajak atau yang disebut dengan Insentif. Namun apabila pihak tesebut tidak menggunakan lahan untuk pelaksanaan ruang terbuka hijau maka akan dikenai dsentif atau pembebanan pajak. Pada prinispnya masayarakat memiliki hak untuk menikmati lingkunga yang bersih, hal itu akan terwujud didalam seberapa baik pemerintah melakukan pelaksanaan prinsip Good Environmental Governance dalam pembagunan kota,sehingga sebaiknya pemerintah tidak melakukaan pelarangan terhadap masyarakat dalam hal partisipasinya terhadap pembagunan, tetapi pemerintah harus mampu menggiring masyarakat untuk melakukan partisipasi pembagunan kota sekaligus melaksanaan pemanfaatan pembagunana tersebut menjadi uang terbuka yang mampu dinikmati oleh khalayak umum. Sebagaimana tertera dalam Pasal 28 UUPR mengenai arahan insentif dan disinsentif, yaitu:

\begin{tabular}{l} 
Arahan insentif \\
\hline Keringanan pajak, pemberian kompensasi, subsidi silang, \\
imbalan, sewa ruang, urun saham
\end{tabular}

Pembangunan serta pengadaan infrastruktur

Kemudahan prosedur perizinan

Pemberian penghargaan kepada masyarakat, swasta dan/atau pemerintah daerah

\section{Arahan disinsentif}

Pengenaan pajak yang tinggi yang disesuaikan dengan besarnya biaya yang dibutuhkan untuk mengatasi dampak yang ditimbulkan akibat pemanfaatan ruang

Pembatasan penyediaan infrastruktur, pengenaan kompensasi dan penalty

Kedua, peran serta masyarakat (participation and representation), dampak dari kemajuan sosial dan ekonomi masyarakat telah membuat tumbuhnya atensi masyarakat dalam meningkatan kelembagaan swadaya. Pengembagan secara sustaining dalam masyarakat adalah merupakan potensi yang harus ditingkatkan. Dapat menjalankan tanggung jawab untuk tercapainya kualitas lingkungan hidup dan memahami arti akan haknya atas lingkungan hdup yang baik adalah salah satu ciri dari kesadaran masyarakat untk dapat mewujudkan kualitas lingkunganya dengan baik.

Kesadaran masyarakat juga dcirikan dengan keberdayaan, yaitu keingginan untuk memiliki lingkungan yang hijau dan bersih. Kemandirian juga merupakan salah satu karateristiknya yaitu munculnya preseketif untuk melakukan dan memeperjuangkan segala bentuk aspirasi didalam masyarakat itu sendiri, dalam rangka memenuhi kebutuhan lingkungan yang hjau dan bersih berdasrkan kengginan yang tumbuh dari budaya adat istiadat, yang untuk menghadapi permasalahan lingkungan disekitar. Undang-Undang Nomor 24 Tahun 1992 tentang Penataan Ruang sebagaimana telah diatur dalam beberapa peraturan perundang-undangan akan hak masyarakat untuk turut serta berpartisipasi dalam pengelolaan lingkungan hidup yang dalam hal ini adalah pengelolaan RTH yaitu diatur dalam Undang-Undang Nomor 24 Tahun 1992 tentang Penataan Ruang terdapat penjaminan atas hak masyarakat untuk mewujudkan Good Environmental Governance dalam bentuk partisipasinya didalam pengelolaan lingkungan hidup. Partisipasi yang dimaksud terdiri dari tiga hal pokok meliputi:

1. Adanya kontribusi yang nyata

2. Hadirnya masyarakat

3. Adanuya usaha untuk ikut serta bertanggung jawab atas suatu usaha.

Dalam pengelolaan ruang terbuka hijau di kota Yogyakarta dalam rangka memenuhi prinsip good environmental governance tedapat bentuk aktivitas masyarakat unutk memenuhi prisnip tersebut, meliputi peranan dalam ruang terbuka hijau dan dalam meningkatkan kualitas lingkungan.

Ketiga, kemudahan Informasi penyediaan informasi yang berkatan dengan pengelolaan lingkungan merupakan tugas pejabat terkait. Adanya ketersediaan infromasi ini terkait dengan infromasi lengkap tentang sumber daya alam dan lingkungan sekitarnya sehingga masyarakat akan dengan mudah menerima informasi terupdate.inilah yang dimaksud dengan pemenuhan hak masyarakat terhadap infromasi lingkungan. Berdasarkan artikel yang ditulis oleh Galih Akbar Prabowo, dalam kaitannya dengan pelayanan informasi publik, pemanfaatan website Pemerintah Kota 
Yogyakarta juga merupakan perwujudan dari peraturan terkait keterbukaan informasi publik yang tertuang dalam Undang- Undang Nomor 14 Tahun 2008 tentang Keterbukaan Informasi Publik. ${ }^{19}$

Keempat, kejelasaan dan pertanggung jawaban, yang dimaksud dengan kejelasaan dan pertanggungjawaban adalah kegiatan pemerintah yang berkaitan dengan pengelolaan lingkungan arus secara jelas memberikan informasi terhadap apa yang sebernanya terjadi melalui sebuah laporan yang dapat dipertanggung jawabkan. Maka hal ini erat hubungan dengan adanya asas transparasi dan akuntabilitas, asas transparasi diperlukan dalam kegiatan pemerintah yang menghasilkan suatu laporan data, sehingga masyarakat mampu mendapatkan kejelasaan informasi terkait pelaksanaan pemerintahan, Sehingga terjadi check and balance. Dikutip dari website resmi pemkot Yogyakarta, bahwa dalam pelaksanaan mengenai pertanggungjawaban atas pengelolaan lingkungan yang telah dilakukan, bersamasama dengan para pelaku usaha yang juga memanfaatkan keberadaan lingkungan sebagai salah satu factor yang menunjang kegiatan bisnis mereka, melakukan kegiatan pelaporan pertanggungjawaban atas kegiatan pengelolaan lingkungan. ${ }^{20}$ Terlepas dari konflik antara industri dan otoritas pemerintah selama negosiasi peraturan lingkungan yang baru, beberapa perusahaan telah berusaha untuk mengambil pendekatan proaktif terhadap pengelolaan lingkungan, yang didorong oleh motif keuntungan yang kuat. Namun, dalam banyak kasus, pengelolaan lingkungan belum menjadi tujuan itu sendiri. ${ }^{21}$ Tujuan utamanya adalah untuk meningkatkan citra publik perusahaan agar tetap kompetitif. ${ }^{22}$ Menurut Salter, tanggapan perusahaan tradisional terhadap rezim peraturan yang lebih ketat adalah dengan menyatakan bahwa efek dari tekanan pasar, meningkatnya tanggung jawab sosial perusahaan dan kesadaran lingkungan adalah cara yang lebih baik untuk mencapai perlindungan lingkungan. ${ }^{23}$

Kelima, adanya pendelegasiaan:, pemerintah pusat adalah yang mempunyai kewengan untuk mengelola lingkungan melalui kementerian terkait, Pengelolaan sumber daya alam harus dilakukan oleh pemerintah daerah atas pendelegasian pemerintah pusat, alasanya pemerintah pusat berada jauh dari sumber daya alam dan potensi dari daerah berkiatan dengan segala asepeknya, khusnya sumber daya alam dan lingkungan dipastiakan pemerintah daerah lebih kompten dibandingkan dengan pemerntah pusat. Pedelegasian tersebut disebut juga dengan desentralisasi yaitu pelimpamhaan kewenangan yang diberikan pemerintah pusat kepada pemerntah daerah untuk mengelolaa rumah tangga sendiri. Menurut artikel yang ditulis Nopyandri, dengan judul "hak atas lingkungan hidup dan kaitannya dengan peran serta dalam pengelolaan lingkungan hidup dalam perspektif otonomi daerah Berkaitan dengan pelaksaanan pengelolaan sumber daya alam berdasar pasal 33 UUD 1945, bumi air dan kekayaan alam dikuasi oleh Negara. Artinya negara memiliki kewenagan untuk mengelolanya sedangkan masyarakat diberikan hak unutk menikmati sumber daya alam yang telah dikelola negara sehingga tercipatalah kemakmuraan dan kesejahteraan rakyat. 24

Keenam, tuntutan hak dan keadilan masyarakat yogyakarata diberikan hak seluas luasnya untuk menggunakan layanan peradilan, sehingga hak hak masyarakat akan terjamin dan mampu meningkatkan akuntabilitas pelayanan peradilan. Hal tersebut dilakukan untuk memenuhi asas keadilan, dalam bentuk kemudahan dalam menuntut hak masyarakat berkait dengan lingkungan, hak masyarakat untuk mendapatakan informasi, hak masyarakat untuk berpartisipasi,dan masyarakat untuk melakukan pengawasan terhadap pengelolaan ruang terbuka hijau oleh pemerintah serta layanan peradilan. Menurut Muzakkir Abubakar, pasal 65 UU No. 32 tahun 2009 dijelaskan bahwa setiap orang mempunyai hak atas lingkungan hidup yang baik dan sehat, mendapakan pendidikan lingkungan hidup, akses informasi, akses partisipasi dan akses keadilan, mengajukan usul dan/atau keberatan terhadap rencana usaha dan/atau kegiatan yang diperkirakan dapat menimbulkan dampak terhadap lingkungan hidup, berperan dalam perlindungan dan pengelolaan, melakukan pengaduan akibat dugaan pencemaran dan/atau perusakan lingkungan hidup. ${ }^{25}$ Apabila hak-hak tersebut tidak terpenuhi serta menimbulkan kerugian baik bagi dirinya sendiri atau kemaslatan umum warga masyarakat, maka setiap orang atau warga masyarakat dapat mengajukan penyelesaian sengketa lingkungan tersebut melalui cara perdamaian di luar pengadilan (nonlitigasi) atau melalui lembaga

${ }^{19}$ Galih Akbar Prabowo, "Pengelolaan Konten Website Pemerintah Kota Yogyakarta Sebagai Media Pelayanan Publik," Dialogia 16, no. 1 (2019): 118-37, https://doi.org/10.21154/dialogia.v16i1.1496. Hlm 125

20 Intan, "Kegiatan Sosialisasi Pelaporan Pengelolaan Lingkungan Perusahaan Dan Sosialisasi Pelaporan Online 'SILALING' Untuk Perusahaan,” 2019, https://lingkunganhidup.jogjakota.go.id/detail/index/222. Akses 5 November 2020

${ }^{21}$ D M Ong, op cit. hlm 713

${ }^{22}$ Gary Haq et al., "Determining the Costs to Industry of Environmental Regulation," European Environment 11, no. 3 (2001): 125-39, https://doi.org/10.1002/eet.257. Hlm 129

${ }^{23}$ Salter, Corporate Strategies and Responses in Environmental Regulation Frontiers of Environmental Law, in O. Loma (London: Chancery Law, 1991). Hlm 26

${ }^{24}$ Nopyandri, "Hak Atas Lingkungan Hidup Dan Kaitannya Dengan Peran Serta Dalam Pengelolaan Lingkungan Hidup Dalam Perspektif Otonomi Daerah" (2014) 7:3 J Inov 33-44. Hlm 39

${ }_{25}$ Muzakkir Abubakar, "Hak Mengajukan Gugatan Dalam Sengketa Lingkungan Hidup," Kanun Jurnal Ilmu Hukum 21, no. 1 (2019): 93-108. Hlm 100 
pengadilan (litigasi). Walaupun hingga saat ini, kegiatan penuntutan hak bagi seseorang yang menderita kerugian/terkena resiko masih sulit ditegakkan. ${ }^{26}$

\section{SIMPULAN}

1. Kota Yogyakarta menjadi kota yang mengutamakan kelestarian lingkungan. Penyediaan kawasan ruang terbuka hijau di kota Yogyakarta bila dilihat dari ketentuan yang ada pada undang undang 26 tahun 2007 sudah maksimal, namun kota Yogyakarta masih memiliki beberapa tantagan yang harus diselesaikan terkait penyediaan kawasan ruang terbuka hijau. Tantangan tersebut adalah dengan Banyaknya kriteria yang terdapat di dalam Peraturan Menteri Dalam Negeri Nomor 4 tahun 1996 tentang Ruang Terbuka Hijau, bukan berarti memperbesar kemungkiinan mudahnya penentuan ruang terbuka hijau di kota Yogyakarta. Hal ini dikarenakan di dalam Pertaturan Daerah Kota Yogyakarta Nomor 2 Tahun 2010 tentang Rencana Tata Ruang Wilayah Kota Yogyakarta bahwa penyediaan kawasan ruang terbuka hijau harus didasarkan pada asas kemanfaatan dan asas kelestarian.

2. Kota Yogyakarta dalam menerapkan prinsip good environmental governance untuk penyediaan ketersediaan ruang terbuka hijau dengan menggunakan Teori Belbase: pembatas kewenagan oleh hukum, peran serta masyarakat, kemudahan Informasi penyediaan informasi yang berkatan dengan pengelolaan lingkungan merupakan tugas pejabat terkait, kejelasaan dan pertanggung jawaban, pendelegasiaan, tuntutan hak dan kewajiban masyarakat.

\section{DAFTAR PUSTAKA}

\section{Buku}

Budiati. Good Governance Dalam Pengelolaan Lingkungan Hidup. Bogor: Ghalia Indonesia, 2012.

Hosio, J.E. Kebijakan Publik Dan Desentralisasi Esai Dari Sorong. Yogyakarta: Laksbang, 2007.

Kodoatie Dan Syarief. Tata Ruang Air. Yogyakarta: Andi Offset, 2010.

Mirsa, And Rinaldi. Elemen Tata Ruang Kota. Yogyakarta: Graha Ilmu, 2011.

Rian Nugroho. Metode Penelitian Kebijakan. Yogyakarta: Pustaka Pelajar, 2013.

Sadyohutomo, And Mulyono. Manajemen Kota Dan Wilayah Realita Dan Tantangan. Jakarta: Bumi Aksara, 2009.

Salter. Corporate Strategies And Responses In Environmental Regulation Frontiers Of Environmental Law. In O. Loma. London: Chancery Law, 1991.

Siahaan, N.H.T. Hukum Lingkungan Dan Ekologi Pembangunan. Jakarta: Erlangga, 2004.

Sugiyono. Metode Penelitian Kuantitatif, Kualitatif Dan R\&D. Bandung: Alfabeta, 2009.

Suharto, Edi. Membagun Masyarakat Memberdayakan Masyarakat: Kajian Strategis Pembagunan Kesejahteraan Sosial Dan Pekerjaan Sosial. Bandung: Refika Aditama, 2006.

Wigjoesoebroto, Soetandyo. Hukum Dalam Masyarakat. Jakarta: Rajawali, 1986.

\section{Jurnal}

Abubakar, Muzakkir. "Hak Mengajukan Gugatan Dalam Sengketa Lingkungan Hidup.” Kanun Jurnal Ilmu Hukum 21, No. 1 (2019): 93-108

Haq, Gary, Peter D. Bailey, Michael J. Chadwick, John Forrester, Johan Kuylenstierna, Gerald Leach, Delia Villagrasa, Malcolm Fergusson, Ian Skinner, And Sebastian Oberthur. "Determining The Costs To Industry Of Environmental Regulation.” European Environment 11, No. 3 (2001): 125-39. Https://Doi.Org/10.1002/Eet.257.

Lisdiyono, Edy. "Penyelesaian Sengketa Lingkungan Hidup Haruskah Berdasarkan Tanggung Jawab Mutlak Atau Unsur Kesalahan." Spektrum Hukum 11, No. 2 (2014): 67-76.

Nopyandri. "Hak Atas Lingkungan Hidup Dan Kaitannya Dengan Peran Serta Dalam Pengelolaan Lingkungan Hidup Dalam Perspektif Otonomi Daerah.” Jurnal Inovatif 7, No. 3 (2014): $33-44$. Https://Doi.Org/10.7591/Cornell/9780801452505.003.0003.

Ong, D. M. "The Impact Of Environmental Law On Corporate Governance: International And Comparative Perspectives." European Journal Of International Law 12, No. 4 (2001): 685-726. Https://Doi.Org/10.1093/Ejil/12.4.685.

Prabowo, Galih Akbar. "Pengelolaan Konten Website Pemerintah Kota Yogyakarta Sebagai Media Pelayanan Publik.” Dialogia 16, No. 1 (2019): 118-37. Https://Doi.Org/10.21154/Dialogia.V16i1.1496.

Schutter, Olivier. "The Green Rush: The Global Race For Farmland And The Rights Of Land Users." Harvard International Law Journal 52, No. 2 (2011): 503-59.

${ }^{26}$ Edy Lisdiyono, "Penyelesaian Sengketa Lingkungan Hidup Haruskah Berdasarkan Tanggung Jawab Mutlak Atau Unsur Kesalahan," Spektrum Hukum 11, no. 2 (2014): 67-76. Hlm 70 
Berliant Pratiwi dan Eko Priyo Purnomo, Analisa Undang-Undang 26 Tahun 2007 terhadap Penyediaan Ruang Terbuka Hijau Berdasarkan Prinsip Good Environmental Governance Di Kota Yogyakarta

\section{Skripsi/Tesis}

Faizah, Fitrina. "Model Sistem Dinamis Ruang Terbuka Hijau Kota Medan Berdasarkan Faktor - Faktor Lingkungan (Studi Kasus Di Kecamatan Medan Polonia Dan Medan Area).” Universitas Sumatera Utara, 2012.

\section{Web}

Wicaksono, Pribadi. "Kiat Pemkot Yogyakarta Membuat Wilayahnya Makin Asri'," 2020. Https://Travel.Tempo.Co/Read/1310249/Kiat-Pemkot-Yogyakarta-Membuat-Wilayahnya-Makin-Asri. Akses 19 Oktober 2020

Purnomo Hadi. "Peran Ruang Terbuka Hijau Dalam Pengendalian Kualitas Udara Di Dki Jakarta." Institut Pertanian Bogor, 1995. Http://Repository.Ipb.Ac.Id/Handle/123456789/955. Akses 20 Oktober 20208

Intan. "Kegiatan Sosialisasi Pelaporan Pengelolaan Lingkungan Perusahaan Dan Sosialisasi Pelaporan Online 'Silaling' Untuk Perusahaan,” 2019. Https://Lingkunganhidup.Jogjakota.Go.Id/Detail/Index/222. Akses 5 November 2020 